\title{
Promising options for improving performance and proanthocyanidins of the forage legume sainfoin (Onobrychis viciifolia Scop)
}

\section{Review Article}

Author(s):

Kölliker, Roland; Kempf, Katharina; Malisch, Carsten S.; Lüscher, Andreas

Publication date:

2017-08

Permanent link:

https://doi.org/10.3929/ethz-b-000171595

Rights / license:

In Copyright - Non-Commercial Use Permitted

Originally published in:

Euphytica 213(8), https://doi.org/10.1007/s10681-017-1965-6 
1 Promising options for improving performance and proanthocyanidins

2 of the forage legume sainfoin (Onobrychis viciifolia Scop.)

3 SELF-ARCHIVE VERSION -- THE FINAL PUBLICATION IS AVAILABLE AT

4 HTTP://LINK.SPRINGER.COM -- DOI 10.1007/s10681-017-1965-6

5

6 Roland Kölliker ${ }^{1,2^{*}}$, Katharina Kempf ${ }^{2}$, Carsten S. Malisch ${ }^{3,4}$, Andreas Lüscher ${ }^{3}$ 7

$10{ }^{1}$ Molecular Plant Breeding, Institute of Agricultural Sciences, ETH Zürich, 8092 Zurich,

11 Switzerland

$12{ }^{2}$ Molecular Ecology, Agroscope, 8046 Zurich, Switzerland

$13{ }^{3}$ Forage Production and Grassland Systems, Agroscope, 8046 Zürich, Switzerland

$14{ }^{4}$ present address: Grass and Forage Science, Christian-Albrechts-Universität zu Kiel, 24118 Kiel,

15 Germany

16

17

18

19

20

29 *Corresponding author:

30 E-mail: roland.koelliker@usys.ethz.ch. Phone: +41 58468 7345. Fax +41 584687201. 
32 Abstract

33 Sainfoin (Onobrychis viciifolia Scop.) is an underutilized perennial forage legume with high 34 potential as a forage source for ruminants in grassland based livestock production systems. The species is also particularly valued for its content of proanthocyanidins (PA; also known as condensed tannins), which have been shown to improve animal health by reducing bloat, and by diminishing gastro-intestinal parasites, can reduce nitrogen losses through excreted urine and may also have the potential to lower methane emissions. However, sainfoin cultivation is not widespread today, mainly due to the limited availability of high performing cultivars and agronomic constraints such as slow establishment, poor competitive ability and limited yield stability. In this paper, we give an overview on the importance and the potential of sainfoin and review recent findings regarding cultivation practices and the variability observed for agronomic and quality traits. A special focus is placed on the potential and implications for targeted improvement through breeding. Results show that stability of sainfoin yields can be significantly improved when grown in mixtures with appropriate companion species and it was shown that the choice of cultivar, management practices and drought could have an impact on PA content and composition. Various studies demonstrate large variability in agronomic performance, PA concentration and PA composition among and within sainfoin accessions, highlighting the big potential to improve this species by breeding. In addition, we highlight recent advances in breeding research such as high rates of selffertilization in this generally allogamous species and the development of molecular genetic resources, which build the basis for novel breeding strategies and the targeted exploitation of sainfoin germplasm in the future. 
63 Temporary and permanent grassland provide the backbone for sustainable livestock production in 64 temperate regions worldwide. They not only cover 37 percent of the earth's surface and significantly contribute to food security, but also have an invaluable potential to store and further sequestrate carbon, regulate water regimes and serve as an important reservoir of biodiversity for both, plant species and pollinating insects (Carlier et al. 2009; O'Mara 2012). In Europe, centuries of grassland farming led to the establishment of distinct plant communities in natural, semi-natural and agriculturally improved grassland, which form an important source of forage for ruminants used in milk and meat production. Even more importantly, a range of forage grass and legume species such as ryegrasses (Lolium spp.), fescues (Festuca spp.), alfalfa (Medicago sativa) and clovers (Trifolium spp.), are sown as forage crops in crop rotations. While monocultures of highly productive grass species produce high forage yields (Humphreys et al. 2010), they require high nitrogen fertilizer input and the forage produced often does not meet the concentrations of crude protein and minerals required for a balanced ruminant diet. Forage legumes on the other hand are particularly valued for their high protein content and their ability to fix atmospheric nitrogen (Frame 2005), but they often cannot provide the energy needed for reaching the full productivity potential of modern livestock breeds. The use of mixed legume - grass swards for forage production not only results in a more balanced composition of the forage, it also substantially reduces the nitrogen fertilizer needs and leads to substantially higher forage yield and higher animal intake (reviewed in Lüscher et al. 2014). In addition, some forage legume species contain specific features such as tannins, polyphenol oxidases or protease enzymes, which may benefit ruminant nutrition, increase animal health and have the potential to reduce greenhouse gas emissions (Kingston-Smith et al. 2010; Mueller-Harvey 2006). Despite a long history of cultivation of a relatively broad range of forage legume species including medics (Medicago spp.), clovers (Trifolium spp.) and vetches (Vicia spp.), today's grassland agriculture largely depends on three main legume species, alfalfa, red clover (T. pratense L.) and white clover (T. repens L.). These are either mainly grown in monoculture (alfalfa) or mixtures (clovers; Annicchiarico et al. 2015). Consequently, breeding efforts and achievements focused on species such as birdsfoot trefoil (Lotus corniculatus L.) and sainfoin (Onobrychis viciifolia Scop.) received only little attention from plant breeders and plant scientists over the past decades (Piano and Pecetti 2010). However, some of these minor legume species may be particularly adapted to specific environments based on their physiological and morphological properties or particularly valuable for animal nutrition due to their content in plant secondary metabolites. Sainfoin may for example be particularly suited for alkaline and drought prone soils, which cover large proportions of Central and Southern Europe (Sölter et al. 2007) and are likely to increase in abundance due to climate change 
(Trnka et al. 2011). In addition, promising concentrations of proanthocyanidins (PA; also referred to as condensed tannins) have been found in different sainfoin accessions and cultivars (Azuhnwi et al. 2011; Häring et al. 2007; Stringano et al. 2012), which, fed in sufficient concentrations, can significantly improve animal health by reducing bloat and by diminishing gastro-intestinal parasites (Azuhnwi et al. 2013b; Wang et al. 2006).

Despite these apparent advantages, sainfoin cultivation is not widespread today, mainly due to the limited availability of high performing cultivars and agronomic constraints such as slow establishment, limited competitive ability and yield stability, as well as sensitivity to water logging (Häring et al. 2008; Heinrichs 1970; Koch et al. 1972). In this paper, we give an overview on the importance and the potential of the underutilized forage legume sainfoin and review recent advances in the area of (i) agronomic practices for constantly high sainfoin yield of good quality (ii) the variability of PA content and composition within and among accessions and its stability over different environments (lack of GxE interactions), building the basis for the selection of improved cultivars and (iii) recent advances in the area of sainfoin genetics and the development of molecular genetic tools. All three together will provide the basis for developing optimized breeding strategies for this orphan forage legume.

\section{Sainfoin - a promising forage legume}

Sainfoin, Onobrychis viciifolia Scop, is a perennial herbaceous forage legume, grown as a forage source for ruminants in grassland based livestock production systems. Its biomass is composed of rather rigid stems and multifoliate leafs with up to 30 pinnate and one terminal leaflet. Sainfoin is usually cut and used fresh or preserved as hay or pellets, while grazing is restricted to dry areas with moderate irrigation (Wilman and Asiedu 1983). In addition, a large potential for silage production has also been reported (Copani et al. 2016; Grosse Brinkhaus et al. 2016). Dry matter yields range between 2 and $12 \mathrm{tha}^{-1}$ and are therefore considerably lower when compared to alfalfa or red clover (Table 1; Frame et al. 1998). However, forage quality remains high even when cut in full flowering stage due to the fact that the leaves are less prone to fall off when compared to alfalfa (Goplen et al. 1991). The species is also particularly valued for its PA content, contributing to animal health and reducing the ecological fingerprint of livestock production as will be discussed in more detail below. Sainfoin is also able to withstand drought spells and to thrive in soils with limited water availability thanks to a long taproot which can reach depths of up to two meters in the soil (Fleischmann 1932). In addition to a strong taproot, sainfoin is characterised by an immense fine root system which can contribute up to $16,200 \mathrm{~kg}$ of dry matter ha ${ }^{-1}$ (four times that of alfalfa), thus significantly improving soil fertility (Sergeeva 1955). 
131 Sainfoin belongs to the family Fabaceae, subfamily Faboidae and the tribe Hedysarae. The tribe

132 Hedysarae has a rather controversial taxonomy, but in general it has been accepted for sainfoin to 133 belong to the genus Onobrychis of the section Onobrychis (Woodgate et al. 1999). However, sainfoin 134 still is known under a range of different synonyms such as Hedysarum onobrychis L., O. onobrychis 135 (L.) Karsten, O. sativa Lam., O. viciifolia Scop. subsp. sativa (Lam.) Thell. and O. vulgaris Güldenst. 136 (Porcher 2004). The species is further separated into two botanical types: O. viciifolia Scop. var. 137 communis, the common type, has its origin in Central Europe and is also referred to as the single cut 138 type due to its slow regrowth after the first cut (Badoux 1964), while O. viciifolia Scop. var. bifera 139 Hort., the giant type, with origin in the Middle East is characterised by a faster regrowth after cut and 140 is therefore able to flower two or three times per year (Piano and Pecetti 2010). The species is 141 tetraploid with $2 \mathrm{n}=4 \mathrm{x}=28$ chromosomes. Based on cytological studies and preponderance of 142 tetrasomic gene segregation, autopolyploid inheritance was suggested, but indications for 143 allopolyploid inheritance have also been observed and no conclusive evidence was given so far (De 144 Vicente and Arus 1996; Sacristan 1966).

145 Sainfoin cultivation has a long history and dates back to the $10^{\text {th }}$ century, when it is assumed to have 146 started in today's Armenia (Akopian 2009). From there, sainfoin spread across Europe, where, during 147 the $18^{\text {th }}$ century, it became an important source of roughage for ruminants in countries such as France, 148 Italy, UK, Germany and Switzerland and was also introduced into the USA (Piper 1914). However, 149 with the increased availability of seed from high yielding forage legume species such as red clover 150 and alfalfa, the importance of sainfoin continuously decreased and, despite its numerous advantages, 151 the species is not widespread in today's intensive agriculture with high fertilizer inputs and cutting 152 frequencies. Consequently, breeding activities have remained on a very low level with only a few 153 listed sainfoin cultivars available (European Commission 2015). The main reasons for the poor 154 representation of sainfoin in productive grassland systems are its lower yield when compared to other 155 forage legumes, its poor competitive ability in early establishment, a limited persistence, 156 susceptibility to waterlogging (Liu et al. 2010; Sheehy and Popple 1981), low tolerance to frequent 157 cutting (Malisch et al. 2017) and susceptibility to diseases such as powdery mildew or phytophthora 158 root rot (Sears et al. 1975). Agronomic practices for high sainfoin yield of good quality

161 Improved mixtures for more stable sainfoin yields

162 One of the main issues with sainfoin cultivation is its low competitive ability, which makes it 163 particularly vulnerable to competition by weeds or, when grown in mixtures, by partner species 164 (Häring et al. 2008). While weed control through herbicides is cost-intensive and may have undesired 165 environmental effects, grass-legume mixtures offer the possibility to significantly decrease the 
invasion of unsown species in mixed stands (Connolly et al. 2017; Sanderson et al. 2012). However, in sainfoin some partner species were found not only to considerably suppress weed infestations, but also lead to a drastically reduced sainfoin yield when compared to monoculture (Häring et al. 2008). This may have been due to an inappropriate choice of the partner species or an unfavourable sowing density, which would allow the partner to establish too quickly. In a recent study with three sainfoin cultivars and six companion species, sainfoin-grass mixtures showed considerably lower shares of unsown species (2 to 4\%) when compared to sainfoin monocultures (15\%; Malisch et al. 2017). Although yield patterns in the different mixtures / monocultures varied to some extent over the years, on average mixtures showed an annual total yield of $16.5 \mathrm{t} \mathrm{ha}^{-1}$, which was higher by $33 \%$ than the mean yield of partner species in monoculture and by $21 \%$ when compared to sainfoin monoculture.

Comparable effects such as transgressive overyielding are a feature of multispecies grass-legume mixtures where partner species optimally complement each other and $\mathrm{N}$ fertilizer input is moderate (reviewed in Lüscher et al. 2014).

Although it is unclear which proportions of sainfoin are needed to optimally profit from its benefits, Wang et al. (2006) found that $35 \%$ of sainfoin in mixtures is sufficient to reduce bloat in grazing steers by $77 \%$. In general, a legume proportion of 30 to $50 \%$ was identified to be ideal in terms of biomass and protein yield and forage quality (Lüscher et al. 2014; Suter et al. 2015). In this respect, mixtures with meadow fescue (F. pratensis) and perennial ryegrass (L. perenne) appear particularly valuable, as they resulted in consistently high sainfoin proportions of 38 to 63\% (Malisch et al. 2017). The choice of appropriate cultivars may also substantially influence sainfoin yield, as the cultivar Perly achieved higher sainfoin yields and suppressed weeds better, in both, monocultures and mixtures than did the two other cultivars (Malisch et al. 2017). This result stresses the importance of cultivars with increased performance, especially with increased competitive ability (against weeds and the mixture partner). Strategies to achieve this include breeding for high yields in general (independent of monoculture or mixture) and breeding for high performance derived from the adaptation to specific mixture partners (Hill 1990; Lüscher et al. 1992; Lüscher and Jacquard 1991; Zuppinger-Dingley et al. 2014). Indeed, Sottie et al. (2014) report the development of a sainfoin population especially adapted for cultivation in mixtures with alfalfa.

\section{Symbiotic $N_{2}$ fixation and drought tolerance}

In addition to its benefit to animal health through its content of PAs and other polyphenolic compounds, high sainfoin proportions in the sward may also substantially contribute to sustainable livestock production through symbiotic nitrogen fixation. It was often argued that insufficient $\mathrm{N}_{2}$ fixation could be one factor contributing to the poor performance of sainfoin (Mora-Ortiz and Smith 2016). However, recent results demonstrate, that sainfoin can fix up to $168 \mathrm{~kg} \mathrm{~N} \mathrm{ha}^{-1}$ via symbiosis, 
with the proportions of apparent $\mathrm{N}$ derived from the atmosphere ranging from $70 \%$ (monoculture) to

$20284 \%$ (in mixture with perennial ryegrass), regardless whether seed was previously inoculated with rhizobia or not (Malisch et al. 2017). This range was comparable to other legume species under comparable growth conditions (Nyfeler et al. 2011; Oberson et al. 2013).

Sainfoin is able to withstand drought stress thanks to its large taproot. Although biomass reductions of up to $37 \%$ have been observed in sainfoin after 14 weeks of drought, plants were able to persist and regrow even under very low water availability (Malisch et al. 2016). In addition, considerable drought tolerance has been observed in sainfoin ecotypes, which provides the basis for further improvement of this important trait (Irani et al. 2015).

Concentration and structural composition of PAs

212 PAs are polymers of flavan-3-ol subunits and are commonly found in most woody plants such as 213 grapevine (Vitis vinifera), tea (Camellia sinensis) or pome fruits and are also present in several legume 214 species (Dixon et al. 2005). Sainfoin has been shown to contain significantly higher amounts of PAs 215 when compared to other forage legume species such as white clover or alfalfa (Aufrere et al. 2013; 216 Azuhnwi et al. 2013a) or to be higher yielding and more competitive compared to other PA containing 217 legumes such as big trefoil (L. pedunculatus) or birdsfoot trefoil (Häring et al. 2008; Häring et al. 2007). PAs are a highly diverse group of tannins, which can be further characterised by the proportion of their flavanol units belonging to procyanidins (PC, i.e. catechin or epicatechin) or prodelphinidins (PD, i.e. gallocatechin or epigallocatechin) and the length of the oligomer or polymer chains. Many different PA structures including very long polymers exceeding $30 \mathrm{kDa}$ have been identified in plant species (Bravo 1998). In ruminants, PAs in the diet are associated with a broad range of benefits, some of which are well understood while other need further research to fully exploit their potential (Lüscher et al. 2014; Mueller-Harvey 2006). For example, PAs have the potential to precipitate proteins by means of non-covalent hydrogen bonds between the phenolic groups of the PA and the amide groups of the protein. In ruminants fed with protein rich diets, protein use efficiency is often low due to very rapid protein degradation in the rumen which inhibits the complete utilization of amino acids by rumen microbes (Broderick and Albrecht 1997). If PAs are present, proteins are precipitated, which increases the fraction of rumen escape proteins and leads to lower protein digestibility in the rumen. This not only leads to reduced $\mathrm{N}$ losses through excreted urine, it may also lead to faster animal growth rates and increased milk production (Girard et al. 2016; Waghorn 2008). Protein precipitation in the rumen also reduces fermentation gas accumulation and the formation of stable foams, which both lead to bloat and may cause animal death (Sottie 2014; Wang et al. 2012). PAs have also been shown to play a role in the control of gastrointestinal parasites by reducing the nematode fecundity and by improving the animal's immune response (Hoste et al. 2012). Other 
benefits of PAs in the diet include potential reduction of methane emissions (Hatew et al. 2015) and increased quality of animal products for human consumption (Girard et al. 2016).

238 The PA concentrations in a forage, as well as their composition influence the positive effects Pas can have on ruminants. PAs in plants are constructed of either PC or PD subunits or of oligomers and polymers containing both, PC and PD subunits. This composition substantially influences bioactive properties of PAs. For example, susceptibility of parasites has been shown to strongly depend on PA structure, with PD-rich PAs generally showing higher anthelmintic properties when compared to PCrich PAs (Kommuru et al. 2014; Quijada et al. 2015). However, PDs might result in decreased PAprotein dissociation in the abomasum and thus, in decreased nitrogen use efficiency (Mueller-Harvey 2006). In order for sainfoin to be widely used as a health promoting forage for ruminants, and to improve these traits through targeted breeding, detailed information on PA content and composition in cultivars and individual plants is needed.

\section{High variability fosters opportunities for breeding}

High variability in concentration and composition of PAs

Although several studies have demonstrated positive effects of sainfoin on animal health and nutrition, due to analytical limitations, these studies largely focused on analysing total PA content rather than PA composition, relying on methods such as thiolysis or HCl-butanol extraction (e.g. Azuhnwi et al. 2013a; Azuhnwi et al. 2011). Recently, a novel method for UPLC-MS/MS analysis has been developed which allows efficient characterisation of PA composition for characteristics such as the mean degree of polymerization $(\mathrm{mDP})$ or $\mathrm{PC} / \mathrm{PD}$ ratios on a large number of individual plants (Engström et al. 2014). This method was used to investigate PA content and composition in 27 sainfoin accessions and large variation in average PA concentration in leaves was found across all accessions ranging from $23.0 \mathrm{mg} \mathrm{g}^{-1} \mathrm{DM}$ to $47.5 \mathrm{mg} \mathrm{g}^{-1} \mathrm{DM}$ (Table 1; Malisch et al. 2015). Interestingly, average leaf PA concentrations were higher for ecotype populations when compared to cultivars and landraces. This may have been due to the fact that breeding of sainfoin largely focused on yield and persistence (Goplen et al. 1991) and shows the potential of untapped germplasm for increasing PA in sainfoin. As expected for an outbreeding species, large variability in PA content and composition was also observed between individual plants within accessions. PA content and composition is also known to vary considerable within the plant, with young leaves having highest and stems having lowest concentrations (Regos et al. 2009). In addition, sainfoin leaves appeared to better meet the PA composition required for optimal health and nutritional benefits. They had longer polymers and higher PD proportions when compared to stems and were also found to have higher concentrations of rutin (quercetin- $O$-rutinoside) and nicotiflorin (kaempferol-O-rutinoside; Malisch 
et al. 2015), both these components have been shown to enhance anthelmintic properties of PAs

271 (Barrau et al. 2005).

\section{Increasing PA yield}

In order to improve sainfoin as a bioactive forage, not only PA concentration and composition, but also PA yield per se needs to be improved. Potentially, increasing biomass yield could restrict the increase of PA concentration through dilution, based on the fact that plant resources are limited and can only be allocated to either growth or the production of plant secondary metabolites (Stamp 2003). Indeed, a certain trade-off between plant yield and leaf PA concentration was observed for sainfoin, but this trade-off was comparatively small and was restricted to very small plants, which were in a yield range not relevant to plant breeders. As a consequence, the amount of PAs harvested per plant was significantly higher for cultivars (332 mg plant ${ }^{-1}$ ) when compared to ecotype accessions (256 mg plant $^{-1}$; Malisch et al. 2015). In addition, no trade-off was found for PA composition and plant yield. Therefore, further yield gains could be possible without compromising PA content and composition in sainfoin (Malisch et al. 2015). Thus, the variability in sainfoin germplasm together with the analytical tools available, provide the basis for effective selection of sainfoin genotypes with an ameliorated PA content and composition.

\section{Influence of growth stages and environment on PA properties}

Another issue when growing sainfoin as a bioactive forage is the stability of PA content and composition across ontogenetic stages of the plant, growing seasons and different environments. The latter may be particularly important with regard to increasing occurrences of drought periods and rising temperatures through the impact of climate change (Trnka et al. 2011). In a large-scale experiment where artificial drought was imposed through rain-out shelters, PA concentration and composition were significantly affected by drought, but also clearly differed between plants in the vegetative and flowering stage, respectively (Malisch et al. 2016). Vegetative plants under drought showed significantly higher PA concentrations in their leaves when compared to rainfed control plants, but also when compared to plants in the reproductive stage exposed to drought. However, the simultaneous analysis of dry matter yield allowed to demonstrate, that increased PA concentrations under drought are presumably rather due to reduced biomass yield than to increased PA synthesis (Malisch et al. 2016).

PA content of sainfoin has been shown to be highly variable among cultivars and accessions (Azuhnwi et al. 2013a; Malisch et al. 2015; Stringano et al. 2012). Averaged over years, different environments and treatments, these differences may be as high as $45 \%$ between the accessions with the highest and the lowest PA concentration, respectively. However, all accessions responded 
similarly to drought with respect to the PA concentration and composition and there was no accession

$306 \mathrm{x}$ drought interaction observed (Malisch et al. 2016). Thus, the ranking of accessions regarding their

307 PA characteristics was independent of the environment. This, together with the high variability 308 observed for agronomic and quality traits, offers a unique opportunity for the improvement of sainfoin 309 through breeding.

310 PAs not only provide various benefits when fed to animals, they have also been shown to play an 311 important role in plant resistance to pathogens and pests (reviewed in Treutter 2006). In sainfoin, 312 concentrations of PA in the leaves were negatively correlated with the occurrence of sainfoin rust 313 (Uromyces onobrychis (Desmazières) Léveillé), indicating that PAs may play a role in sainfoin's 314 resistance to rust diseases (Malisch et al. 2016).

\section{Sainfoin - a PA plant with high potential}

317 The high variability observed in biomass yield, PA content and PA composition within and between 318 cultivars of sainfoin (Malisch et al. 2015) is characteristic for outbreeding forage grass and legume 319 species which are mainly bred through population improvement and the development of synthetic 320 cultivars consisting of many different genotypes (Posselt 2010). In order to optimally exploit the 321 bioactive properties of sainfoin, PAs in different quantities and of different structural characteristics are needed. While it is commonly accepted that higher PD proportions and higher mDP (i.e. longer polymer sizes) improve anthelmintic properties and influence rumen in vitro methane production (Hatew et al. 2015; Novobilsky et al. 2013), their effect on other aspects of animal nutrition is poorly understood. PAs with high PD proportions have been shown to effectively reduce rumen escape proteins. Although desirable from an environmental point of view, PAs at too high concentrations could lead to anti-nutritional effects by limiting protein use efficiency of the animal (Waghorn 2008). Thus, in the future sainfoin with different PA composition are needed to fulfil specific demands for bioactive effects. The large variability in PA content and composition present in sainfoin, which has been shown to be rather stable across different environments, lays the basis for targeted improvement and utilization in the future (Malisch et al. 2015; Malisch et al. 2016; Malisch et al. 2017).

\section{Genetic resources for a broad range of breeding targets}

The basic prerequisite for the wide adoption of a species in agriculture is the availability of well adapted, high yielding cultivars. Consequently, targeted breeding for forage crop species has been pursued for more than a century and resulted in numerous cultivars of major species such as perennial ryegrass or alfalfa, adapted to a broad range of uses and environments (for overview see Boller et al. 2010a). In sainfoin, breeding activities have been rather scarce and the species has only quite recently gained broader interest (Bhattarai et al. 2016). In Europe, only 22 sainfoin cultivars have been 
reported by the European Commission in 2015, a very low number when compared to the 1,059

341 perennial ryegrass or 380 alfalfa cultivars reported (European Commission 2015). These cultivars 342 mostly originate from a few countries in Eastern and Southern Europe and may be often based on the 343 same breeding material as indicated by the similarity of their names (e.g., Vinovsk, Visnovsky and 344 Višňovský, or Perdix and Perly). A similar situation can be observed in North America, where 345 currently eight cultivars are registered and recommended for cultivation (Bhattarai et al. 2016). With 346 the increasing interest in sainfoin, plant breeding activities are likely to increase. For example, in 347 Canada a new cultivar has been recently released which is characterised by rapid regrowth and which 348 is persistent in mixtures with alfalfa (Acharya 2015).

349 So far, sainfoin breeding has been governed by goals common to most forage species, which include 350 high and stable biomass yield, persistence across a broad range of environments and high forage 351 quality. The variation observed for some of the key breeding targets is summarized in Table 1. 352 Germplasm native to the Near East is well adapted to dry and warm areas and has been shown to 353 clearly outperform cultivars from Western Europe when grown in the dry areas of the USA (Goplen 354 et al. 1991). Although successful cultivars with increased winter hardiness and spring vigour have 355 been developed for Canada (Goplen et al. 1991), there seem to be a general lack of cultivars well 356 adapted to cool season conditions. For example, in New Zealand, the lack of cultivars with sufficient 357 autumn growth and persistence seems to be the main reason for the limited importance of sainfoin 358 (Rumball and Claydon 2005). In Europe, the development of cultivars adapted to drought has been 359 successful, but there seems to be a lack of genetic variability for the adaptation to lower temperatures 360 and high soil humidity (Delgado et al. 2008; Liu et al. 2008). Thus, adaptation to wet and cold climates 361 remains one of the biggest challenges for sainfoin breeding. Other breeding goals include persistence 362 when grown with other species, as it is for example practised in Canada, where sainfoin is grown with 363 alfalfa mainly to reduce bloat (Sottie 2014), or resistance to pests and diseases (Piano and Pecetti 364 2010). In addition, quality traits such as content and composition of PAs or other phenolic compounds 365 have been emerging as additional breeding targets (Mueller-Harvey 2006). The high variation found 366 for these traits as reviewed above has indicated vast possibilities for improvement through plant 367 breeding. However, improving all these traits simultaneously remains challenging. For targeted 368 improvement of sainfoin in the future, diverse and well characterised genetic resources are needed. 369 Novel breeding approaches have to be developed based on knowledge on the mode of inheritance of 370 key breeding targets and the development of molecular genetic tools to assist phenotypic selection.

371 Due to its long history of cultivation, there are considerable amounts of genetic resources for sainfoin 372 available worldwide. Some of these resources are catalogued and made available through gene banks 373 such as the U.S. National Plant Germplasm System which lists 298 sainfoin accessions (GRIN 2016), 374 others are represented in local collections from diversity hotspots such as Iran (summarized in 
Bhattarai et al. 2016). In Europe, gene pools can be clearly separated according to their geographic origin (i.e. Western Europe, Eastern Europe and Asia) based on molecular genetic analyses (Demdoum et al. 2012; Hayot Carbonero et al. 2012; Kempf et al. 2016), which is in accordance to the geographic clusters as exhibited in their PA concentration and composition (Stringano et al. 2012). In addition, high levels of diversity for agronomic and quality traits were observed within and among sainfoin accessions from Spain (Delgado et al. 2008) and Iran (Mohajer et al. 2013; Table 1). The high genetic variation available in sainfoin germplasm collections provides an invaluable resource for further improvement of the species through targeted breeding.

\section{New knowledge for improved breeding strategies}

Sainfoin - a highly self-fertilizing allogamous species

In order to develop optimal breeding strategies, detailed knowledge on the mode of reproduction of the species is indispensable. While autogamous (self-fertilizing) plant species are particularly suited for the development of pure lines and hybrid cultivars, allogamous (cross-fertilizing) species are often bred as population based cultivars, maintaining a high level of genetic diversity within cultivars, which enables broader adaptation to a wide range of environmental conditions. Sainfoin is generally considered to be an allogamous species, depending on insects for pollination (Bennett et al. 2001; Tasei 1984). In contrast to other allogamous forage species such as perennial ryegrass or red clover, where allogamy is secured through gametophytic self-incompatibility controlled by two or one genetic loci, respectively (Do Canto et al. 2016; Riday and Krohn 2010), no such self-incompatibility system has been described for sainfoin. Rather, allogamy is fostered by the flower architecture, with the position of pistil and anthers largely preventing self-pollination (Knuth 1906; Özbek 2011). Such a system is usually less effective in preventing self-fertilization when compared to gametophytic or sporophytic self-incompatibility. Consequently, seed development after self-pollination has been observed for sainfoin, confirming the possibility for self-fertilization in this species (Knipe and Carleton 1972; Thomson 1938). A surprisingly high rate of self-fertilization of 48.5 to $64 \%$ was observed in three $F_{1}$ populations obtained through targeted bi-parental bee-pollination in the greenhouse, while rates of self-fertilization in multi-parental natural populations in the field were well below 5\% (Kempf et al. 2015). The high rates of self-fertilization observed in bi-parental populations may be an effect of limited pollen availability in the glasshouse due to differences in flowering time between the two parental plants. However, the results show that self-fertilization in sainfoin can be quite frequent, which has direct implications on breeding practices. Polycross breeding schemes (Posselt 2010) need to be composed of parental combinations with synchronous flowering time and targeted pair-crosses may require the emasculation of maternal plants. Self-fertilization in allogamous species is often accompanied by inbreeding depression, which results in a severe reduction of 
agronomic performance. While this is particularly severe in species with strong self-incompatibility such as perennial ryegrass (Kölliker et al. 2005) or red clover (Taylor and Anderson 1980), plant height, vigour and seed yield were significantly reduced in sainfoin progeny derived from selffertilization when compared to progeny from cross-fertilization (Kempf et al. 2015). In a natural tetraploid species such as sainfoin, inbreeding may be particularly pronounced through the loss of tetra allelic interactions in the first few generations of inbreeding (Bingham et al. 1994; Gallais 2003). Thus, although the possibility of self-fertilization in sainfoin may open new avenues for plant breeding such as the development of inbred lines or hybrid breeding, care has to be taken to avoid problems associated with severe inbreeding depression.

\section{New developments in molecular genetics and genomics}

Rapid developments in molecular genetics and genomics have generated a range of new tools and strategies which have been shown to valuable complement phenotypic breeding approaches (Varshney et al. 2005). Although novel approaches such as genotyping by sequencing (Elshire et al. 2011) may be readily applied to any species, most approaches require the availability of molecular marker or genome sequence information for the species under study. As an orphan species, such resources are scarce for sainfoin and most studies on genetic composition have been largely based on universal marker systems such as internal transcribed spacer regions (ITS; Hayot Carbonero et al. 2012), inter SSR (reviewed in Bhattarai et al. 2016), SRAP markers (Kempf et al. 2015; Kempf et al. 2017) or sequence specific SSR markers derived from other species (Demdoum et al. 2012). In an attempt to close this knowledge and resource gap, Mora-Ortiz et al. (2016) sequenced the transcriptome of seven day old seedlings of five sainfoin genotypes from five different cultivars using RNA-Seq (Wang et al. 2009). De novo assembly resulted in 92,772 transcripts, of which 63 were annotated to be involved in the PA biosynthesis pathway (Mora-Ortiz et al. 2016). Interestingly, a higher percentage of the PA biosynthesis related transcripts were expressed at high levels when compared to all other transcripts, indicating a high expression of PA related genes even at very early stages of plant development. These genes could be interesting targets when aiming to optimise PA content and composition of sainfoin. Phylogenetic analysis revealed sainfoin to be closely related to red clover which also has a haploid chromosome number of seven. However, it was also closely related to M. truncatula, possibly due to genome duplication and tetraploidy (Mora-Ortiz et al. 2016). Among the five sainfoin genotypes, 77,000 putative single nucleotide polymorphism (SNP) were identified after stringent filtering. However SNP identification proved to be challenging, mainly due to the tetraploidy of sainfoin and the lack of a reference genome which make the distinction between homeologous and allelic SNPs difficult (Peralta et al. 2013). However, the RNA-seq approach allowed for cost-effective identification of 3786 SSR loci (Mora-Ortiz et al. 2016). After testing 400 
SSR primer combinations, Kempf et al. (2016) developed a set of 101 SSR markers which reliably detected polymorphism among a set of 32 sainfoin genotypes. The set contained genotypes from 29 different accessions, representing a broad range of geographical regions including the Near East, Eastern, Western and Southern Europe as well as the USA. With an average of 11.4 alleles per SSR locus detected across the entire dataset, these species specific sainfoin SSRs proved to be much more informative when compared to SSRs derived from other species (Demdoum et al. 2012). Cluster analysis allowed to separate the 32 sainfoin genotypes into two distinct groups, separating accessions for Western Europe and those from Eastern Europe and the Near East (Kempf et al. 2016). These SSRs provide a highly valuable source of markers for future genetic analyses in sainfoin.

\section{First steps towards marker assisted selection}

The improvement of the main breeding targets for sainfoin, such as biomass yield, increased persistence, PA content and composition and seed yield is rather difficult because phenotyping of these traits is usually labour and cost intensive and they are mostly controlled by multiple genetic loci. Thus, genetic gain through breeding is usually slow for such traits and for alfalfa yearly gains for dry matter yield lower than $0.2 \% \mathrm{y}^{-1}$ have been observed over the past decades (Veronesi et al. 2010). In order to achieve genetic gains necessary to meet present and future demands on high quality forage legume cultivars, novel breeding strategies based on novel cultivar types, marker assisted selection strategies, the integration of field based and genome based selection as well as indirect selection strategies have been proposed (Annicchiarico et al. 2015). A common prerequisite for these strategies is a detailed understanding of the genetic control of the target traits, their interaction and their association with easily scorable molecular markers. Apart from a few studies on the variability of selected traits (for example Azuhnwi et al. 2011; Delgado et al. 2008; Mohajer et al. 2011), information on response to selection or the genetic control of important traits in sainfoin is scarce. Kempf et al. (2017) investigated the variation of a range of agronomic traits and the PA content and composition in a segregating $F_{1}$ population derived from a bi-parental cross of two sainfoin plants. Even in such a narrow cross, the variability observed for traits such as vigour, plant height, seed yield, PA content, PC/PD ratio or individual flavanoids was large. Although some of the agronomic traits and some of the quality traits were correlated among each other, no clear correlation between agronomic and quality traits were identified which would allow to identify an easy target for indirect selection for PA content and composition (Kempf et al. 2017). However, one SRAP marker allele was identified to be significantly associated to the PD proportion, explaining $12.3 \%$ of the observed variation. In addition, several SRAP and SSR markers were observed to be associated with agronomic traits such as seed number plant ${ }^{-1}$, plant height and vigour. These findings provide a first insight into 
the genetic control of important traits in sainfoin and may serve, together with past and future investigations, as the basis for the development of marker assisted breeding strategies.

\section{Conclusions}

Sainfoin is a valuable forage legume but underrepresented in today's agriculture mainly due to its agronomic shortcomings and the limited availability of well adapted cultivars. Its ability to fix atmospheric nitrogen together with its bioactive properties mainly due to its PA content, make it an ideal component of sustainable grassland agriculture which has the potential to mitigate several issues caused by agricultural intensification such as drug resistance of pests and pathogens, nitrogen losses through rumen escape proteins and methane emissions by ruminant livestock. All these benefits have increased the interest in sainfoin over the past years. Recent research has shown that substantial and stable sainfoin yields can be achieved when grown in mixture with appropriate partner species. The large variability in agronomic traits, PA content and composition identified within and between different accessions, together with the fact that no significant genotype $\mathrm{x}$ environment interactions were observed, lay the basis for targeted improvement of sainfoin cultivars with better agronomic performance and with particular contents and compositions of PAs through breeding. This may be further facilitated by recently gained knowledge on sainfoin's mode of reproduction together with the newly developed genetic and genomic resources. Some of these findings will, in the future, have a direct impact on the more widespread cultivation of sainfoin through the increased availability of improved cultivars and recommendations about partner species and management practices. However, in order to optimally utilize the bioactive properties of sainfoin, a more detailed understanding of the mode of action of PAs and their individual components is needed. The rapid advances in the area of analytical chemistry together with developments in molecular genetics and genomics will with no doubt allow for rapid broad scale deployment of "sain foin" (healthy hay) in sustainable livestock agriculture of the future.

\section{Acknowledgments}

We thank the two anonymous reviewers for their helpful comments, which helped to substantially improve this manuscript. This work was partially supported by a European Union Marie Curie training network grant ("LegumePlus" PITN-GA-2011-289377). We are grateful to Prof. Irene Mueller-Harvey, University of Reading, UK, for initiating and leading LegumePlus and for encouraging us to work on this interesting plant species. 


\section{References}

513 Abberton MT, Marshall AH (2010) White clover. In: Boller B, Posselt UK, Veronesi F (eds) Fodder Crops and Amenity Grasses. Handbook of Plant Breeding, vol 5. Springer Science + Business Media, New York, pp 457-476. doi:10.1007/978-1-4419-0760-8

Acharya SN (2015) ACC Mountainview sainfoin (Onobrychis viciifolia subsp. Viciifolia). Can J Plant Sci 95:603-607

Akopian JA (2009) On some wild relatives of cultivated sainfoin (Onobrychis L.) from the flora of Armenia. Crop Wild Rel 7:17-18

Annicchiarico P, Barrett B, Brummer EC, Julier B, Marshall AH (2015) Achievements and challenges in improving temperate perennial forage legumes. Crit Rev Plant Sci 34:327-380 doi:10.1080/07352689.2014.898462

Aufrere J, Dudilieu M, Andueza D, Poncet C, Baumont R (2013) Mixing sainfoin and lucerne to improve the feed value of legumes fed to sheep by the effect of condensed tannins. Animal 7:82-92 doi:10.1017/S1751731112001097

Azuhnwi BN, Boller B, Dohme-Meier F, Hess HD, Kreuzer M, Stringano E, Mueller-Harvey I (2013a) Exploring variation in proanthocyanidin composition and content of sainfoin (Onobrychis viciifolia). J Sci Food Agric 93:2102-2109 doi:10.1002/Jsfa.6119

Azuhnwi BN, Boller B, Martens M, Dohme-Meier F, Ampuero S, Gunter S, Kreuzer M, Hess HD (2011) Morphology, tannin concentration and forage value of 15 Swiss accessions of sainfoin (Onobrychis viciifolia Scop.) as influenced by harvest time and cultivation site. Grass Forage Sci 66:474-487 doi:10.1111/j.1365-2494.2011.00811.x

Azuhnwi BN, Hertzberg H, Arrigo Y, Gutzwiller A, Hess HD, Mueller-Harvey I, Torgerson PR, Kreuzer M, Dohme-Meier F (2013b) Investigation of sainfoin (Onobrychis viciifolia) cultivar differences on nitrogen balance and fecal egg count in artificially infected lambs. J Anim Sci 91:2343-2354 doi:10.2527/Jas2012-5351

Badoux S (1964) Etude des caractères morphologiques, physiologiques et agronomiques de populations d' esparcette (Onobrychis spp.). PhD thesis Nr. 3583, ETH Zurich 
Bal MA, Ozturk D, Aydin R, Erol A, Ozkan CO, Ata M, Karakas E, Karabay P (2006) Nutritive value of sainfoin (Onobrychis viciifolia) harvested at different maturity stages. Pak J Biol Sci 9:205-209 doi:10.3923/pjbs.2006.205.209

Barrau E, Fabre N, Fouraste I, Hoste H (2005) Effect of bioactive compounds from Sainfoin (Onobrychis viciifolia Scop.) on the in vitro larval migration of Haemonchus contortus: role of tannins and flavonol glycosides. Parasitology 131:531-538 doi:10.1017/S0031182005008024

Bennett SJ, Francis C, Reid B (2001) Minor and Under-utilised Legumes. In: Maxted N, Bennett SJ (eds) Plant Genetic Resources of Legumes in the Mediterranean. Kluwer Academic Publishers, Dordrecht, The Netherlands, pp 219-220

Bhattarai S, Coulman B, Biligetu B (2016) Sainfoin (Onobrychis viciifolia Scop.): renewed interest as a forage legume for western Canada. Can J Plant Sci 96:748-756 doi:10.1139/cjps-20150378

Bingham ET, Groose RW, Woodfield DR, Kidwell KK (1994) Complementary gene interactions in alfalfa are greater in autotetraploids than diploids. Crop Sci 34:823-829

Boller B, Posselt UK, Veronesi F (eds) (2010a) Fodder Crops and Amenity Grasses. Handbook of Plant Breeding, vol 5. Springer Science + Business Media, New York. doi:10.1007/978-14419-0760-8

Boller B, Schubiger F, Kölliker R (2010b) Red Clover. In: Boller B, Posselt UK, Veronesi F (eds) Fodder Crops and Amenity Grasses. Handbook of Plant Breeding, vol 5. Springer Science + Business Media, New York, pp 439-455. doi:10.1007/978-1-4419-0760-8

Borreani G, Peiretti PG, Tabacco E (2003) Evolution of yield and quality of sainfoin (Onobrychis viciifolia Scop.) in the spring growth cycle. Agronomie 23:193-201 doi:10.1051/Agro2002082

Bravo L (1998) Polyphenols: chemistry, dietary sources, metabolism, and nutritional significance. Nutr Rev 56:317-333 doi:10.1111/j.1753-4887.1998.tb01670.x

Broderick GA, Albrecht KA (1997) Ruminal in vitro degradation of protein in tannin-free and tannin-containing forage legume species. Crop Sci 37:1884-1891 doi:10.2135/cropsci1997.0011183X003700060037x 
Carlier L, Rotar I, Vlahova M, Vidican R (2009) Importance and functions of grasslands. Not Bot Horti Agrobo 37:25

Connolly J, Sebastià L, Kirwan J, Finn M, Llurba M, Suter M et al. (2017) Weed suppression greatly increased by plant diversity in intensively managed grasslands: a continental-scale experiment. J Appl Ecol:in press

Copani G, Niderkorn V, Anglard F, Quereuil A, Ginane C (2016) Silages containing bioactive forage legumes: a promising protein-rich feed source for growing lambs. Grass Forage Sci 71:622-631 doi:10.1111/gfs.12225

De Vicente M, Arus P (1996) Tetrasomic inheritance of isozymes in sainfoin (Onobrychis viciaefolia Scop.). J Hered 87:54-62 doi:10.1093/oxfordjournals.jhered.a022953

Delgado I, Salvia J, Buil I, Andres C (2008) The agronomic variability of a collection of sainfoin accessions. Span J Agr Res 6:401-407 doi:10.5424/sjar/2008063-333

Demdoum S, Muñoz F, Delgado I, Valderrábano J, Wünsch A (2012) EST-SSR cross-amplification and genetic similarity in Onobrychis genus. Genet Resour Crop Evol 59:253-260 doi:10.1007/s10722-011-9681-x

Dixon RA, Xie DY, Sharma SB (2005) Proanthocyanidins - a final frontier in flavonoid research? New Phytol 165:9-28 doi:10.1111/j.1469-8137.2004.01217.x

Do Canto J, Studer B, Lubberstedt T (2016) Overcoming self-incompatibility in grasses: a pathway to hybrid breeding. Theor Appl Genet 129:1815-1829 doi:10.1007/s00122-016-2775-2

Elshire RJ, Glaubitz JC, Sun Q, Poland JA, Kawamoto K, Buckler ES, Mitchell SE (2011) A robust, simple genotyping-by-sequencing (GBS) approach for high diversity species. PLoS One 6:e19379 doi:10.1371/journal.pone.0019379

Engström MT, Palijarvi M, Fryganas C, Grabber JH, Mueller-Harvey I, Salminen JP (2014) Rapid qualitative and quantitative analyses of proanthocyanidin oligomers and polymers by UPLCMS/MS. J Agric Food Chem 62:3390-3399 doi:10.1021/jf500745y

European Commission (2015) Plant variety catalogues \& databases. http://ec.europa.eu/food/plant/plant_propagation_material/plant_variety_catalogues_databas es/index_en.htm. Accessed 07.06. 2017 
Fleischmann R (1932) Züchtung von zwei neuen Futterpflanzen für Trockengebiete. Der Züchter 4:219-225

Frame J (2005) Forage legumes for temperate grasslands. Science Publishers, Inc., Enfield, USA

Frame J, Charlton JFL, Laidlaw AS (1998) Alsike clover and sainfoin. In: Series CP (ed) Temperate forage legume. CAB International, University of Wisconsin, Madison, WI, USA, pp 279289

Gallais A (2003) Quantitative genetics and breeding methods in autopolyploid plants. INRA, Paris, France

Girard M, Dohme-Meier F, Wechsler D, Goy D, Kreuzer M, Bee G (2016) Ability of 3 tanniferous forage legumes to modify quality of milk and Gruyère-type cheese. J Dairy Sci 99:205-220 doi:10.3168/jds.2015-9952

Goplen BP, Richards KW, Moyer JR (1991) Sainfoin for western Canada. Publication 1470/E. Agriculture Canada, Ottawa, Canada

GRIN (2016) https://npgsweb.ars-grin.gov. Accessed 07.06. 2017

Grosse Brinkhaus A, Wyss U, Arrigo Y, Girard M, Bee G, Zeitz J, Kreuzer M, Dohme-Meier F (2016) In vitro ruminal fermentation characteristics and utilisable CP supply of sainfoin and birdsfoot trefoil silages and their mixtures with other legumes. Animal:1-11 doi:10.1017/S1751731116001816

Häring DA, Scharenberg A, Heckendorn F, Dohme F, Lüscher A, Maurer V, Suter D, Hertzberg H (2008) Tanniferous forage plants: Agronomic performance, palatability and efficacy against parasitic nematodes in sheep. Renew Agr Food Syst 23:19-29 doi:10.1017/S1742170507002049

Häring DA, Suter D, Amrhein N, Lüscher A (2007) Biomass allocation is an important determinant of the tannin concentration in growing plants. Ann Bot 99:111-120 doi:10.1093/aob/mc1227

Hatew B, Hayot Carbonero C, Strigano E, Sales LF, Smith LMJ, Mueller-Harvey I, Hendriks WH, Pellikaan WF (2015) Diversity of condensed tannin structures affects rumen in vitro methane production in sainfoin (Onobrychis viciifolia) accessions. Grass Forage Sci 70:474490 doi:10.1111/gfs. 12125 
Hayot Carbonero C, Carbonero F, Smith LJ, Brown T (2012) Phylogenetic characterisation of Onobrychis species with special focus on the forage crop Onobrychis viciifolia Scop. Genet Resour Crop Evol:1-12 doi:10.1007/s10722-012-9800-3

Heinrichs DH (1970) Flooding tolerance of legumes. Can J Plant Sci 50:435-438

Hill J (1990) The three C's - competition, coexistence and coevolution - and their impact on the breeding of forage crop mixtures. Theor Appl Genet 79:168-176 doi:10.1007/BF00225947

Hoste H, Martinez-Ortiz-De-Montellano C, Manolaraki F, Brunet S, Ojeda-Robertos N, Fourquaux I, Torres-Acosta JF, Sandoval-Castro CA (2012) Direct and indirect effects of bioactive tannin-rich tropical and temperate legumes against nematode infections. Vet Parasitol 186:18-27 doi:10.1016/j.vetpar.2011.11.042

Humphreys M, Feuerstein U, Vandevalle M, Baert J (2010) Ryegrasses. In: Boller B, Posselt UK, Veronesi F (eds) Fodder Crops and Amenity Grasses. Handbook of Plant Breeding, vol 5. Springer Science + Business Media, New York, pp 211-260. doi:10.1007/978-1-4419-07608

Irani S, Majidi MM, Mirlohi A, Karami M, Zargar M (2015) Response to drought stress in sainfoin: Within and among ecotype variation. Crop Sci 55:1868-1880 doi:10.2135/cropsci2014.07.0481

Kaplan M (2011) Determination of potential nutritive value of sainfoin (onobrychis sativa) hays harvested at flowering stage. Journal of Animal and Veterinary Advances 10:2028-2031 doi:10.3923/javaa.2011.2028.2031

Kempf K, Grieder C, Walter A, Widmer F, Reinhard S, Kölliker R (2015) Evidence and consequences of self-fertilisation in the predominantly outbreeding forage legume Onobrychis viciifolia. BMC Genet 16:117 doi:10.1186/s12863-015-0275-z

Kempf K, Malisch CS, Grieder C, Widmer F, Kölliker R (2017) Marker-trait association analysis for agronomic and compositional traits in sainfoin (Onobrychis viciifolia). Genet Mol Res 16 doi: $10.4238 / \mathrm{gmr} 16019483$

Kempf K, Mora-Ortiz M, Smith LM, Kölliker R, Skøt L (2016) Characterization of novel SSR markers in diverse sainfoin (Onobrychis viciifolia) germplasm. BMC Genet 17:124 doi:10.1186/s12863-016-0431-0 
653

654

655

656

657

658

659

660

661

662

663

664

665

666

667

668

669

670

671

672

673

674

675

676

677

678

679

680

Khalilvandi-Behroozyar H, Dehghan-Banadaky M, Rezayazdi K (2010) Palatability, in situ and in vitro nutritive value of dried sainfoin (Onobrychis viciifolia). J Agric Sci 148:723-733 doi:10.1017/S0021859610000523

Kingston-Smith AH, Edwards JE, Huws SA, Kim EJ, Abberton M (2010) Plant-based strategies towards minimising 'livestock's long shadow'. Proc Nutr Soc 69:613-620 doi:10.1017/S0029665110001953

Knipe WJ, Carleton AE (1972) Estimates of Percentage of Self-Pollination and Cross-Pollination in Sainfoin (Onobrychis viciifolia Scop). Crop Sci 12:520-522 doi:10.2135/cropsci1972.0011183X001200040041x

Knuth P (1906) Handbook of flower pollination. vol 2. Claredon Press, Oxford, UK

Koch DW, Hinze GO, Dotzenko AD (1972) Influence of three cutting systems on yield, water use efficiency, and forage quality of sainfoin. Agron J 64:463-467

Kölliker R, Boller B, Widmer F (2005) Marker assisted polycross breeding to increase diversity and yield in perennial ryegrass (Lolium perenne L.). Euphytica 146:55-65 doi:10.1007/s10681005-6036-8

Kommuru D, Barker T, Desai S, Burke J, Ramsay A, Mueller-Harvey I, Miller J, Mosjidis J, Kamisetti N, Terrill T (2014) Use of pelleted sericea lespedeza (Lespedeza cuneata) for natural control of coccidia and gastrointestinal nematodes in weaned goats. Vet Parasitol 204:191-198

Liu Z, Baines RN, Lane GPF, Davies WP (2010) Survival of plants of common sainfoin (Onobrychis viciifolia Scop.) in competition with two companion grass species. Grass Forage Sci 65:11-14 doi:10.1111/j.1365-2494.2009.00714.x

Liu Z, Lane GPF, Davies WP (2008) Establishment and production of common sainfoin (Onobrychis viciifolia Scop.) in the UK. 1. Effects of sowing date and autumn management on establishment and yield. Grass Forage Sci 63:234-241 doi:10.1111/j.13652494.2008.00628.x

Lüscher A, Connolly J, Jacquard P (1992) Neighbour specificity between Lolium perenne and Trifolium repens from a natural pasture. Oecologia 91:404-409 doi:10.1007/BF00317630 
Lüscher A, Jacquard P (1991) Coevolution between interspecific plant competitors? Trends Ecol Evol 6:355-358 doi:10.1016/0169-5347(91)90225-M

Lüscher A, Mueller-Harvey I, Soussana JF, Rees RM, Peyraud JL (2014) Potential of legume-based grassland-livestock systems in Europe: a review. Grass Forage Sci 69:206-228 doi:10.1111/gfs.12124

Malisch CS, Lüscher A, Baert N, Engström MT, Studer B, Fryganas C, Mueller-Harvey I, Salminen J-P (2015) Large variability of proanthocyanidin content and composition in sainfoin (Onobrychis viciifolia). J Agric Food Chem 63:10234-10242 doi:10.1021/acs.jafc.5b04946

Malisch CS, Salminen J-P, Kölliker R, Engström MT, Suter D, Studer B, Lüscher A (2016) Drought effects on proanthocyanidins in sainfoin (Onobrychis viciifolia) are dependent on the plant's ontogenetic stage. J Agric Food Chem 64:9307-9316 doi:10.1021/acs.jafc.6b02342

Malisch CS, Suter D, Studer B, Lüscher A (2017) Multifunctional benefits of sainfoin mixtures: Effects of partner species, sowing density and cutting regime. Grass Forage Sci:in press doi:10.1111/gfs.12278

McMahon LR, Majak W, McAllister TA, Hall JW, Jones GA, Popp JD, Cheng KJ (1999) Effect of sainfoin on in vitro digestion of fresh alfalfa and bloat in steers. Can J Anim Sci 79:203-212 doi:10.4141/A98-074

Mohajer S, Jafari AA, Taha RM (2011) Studies on seed and forage yield in 10 populations of sainfoin (Onobrychis sativa) grown as spaced plants and swards. J Fodd Agric \& Env 9:222227

Mohajer S, Jafari AA, Taha RM, Yaacob JS, Saleh A (2013) Genetic diversity analysis of agromorphological and quality traits in populations of sainfoin (Onobrychis sativa). Aust J Crop Sci 7:1024

Mora-Ortiz M, Smith LJM (2016) Sainfoin - surprising science behind a forgotten forage. Grower's Guide. Cotswold Seeds Ltd., Moreton-in-Marsh, Glucestershire, UK

Mora-Ortiz M, Swain MT, Vickers MJ, Hegarty MJ, Kelly R, Smith LMJ, Skøt L (2016) De-novo transcriptome assembly for gene identification, analysis, annotation, and molecular marker discovery in Onobrychis viciifolia. BMC Genomics 17:756 doi:10.1186/s12864-016-3083-6 
Mueller-Harvey I (2006) Unravelling the conundrum of tannins in animal nutrition and health. J Sci Food Agric 86:2010-2037 doi:10.1002/jsfa.2577

Novobilsky A, Stringano E, Hayot Carbonero C, Smith LM, Enemark HL, Mueller-Harvey I, Thamsborg SM (2013) In vitro effects of extracts and purified tannins of sainfoin (Onobrychis viciifolia) against two cattle nematodes. Vet Parasitol 196:532-537 doi:10.1016/j.vetpar.2013.03.024

Nyfeler D, Huguenin-Elie O, Matthias S, Frossard E, Luscher A (2011) Grass-legume mixtures can yield more nitrogen than legume pure stands due to mutual stimulation of nitrogen uptake from symbiotic and non-symbiotic sources. Agric Ecosyst Environ 140:155-163 doi:10.1016/j.agee.2010.11.022

O'Mara FP (2012) The role of grasslands in food security and climate change. Ann Bot 110:12631270 doi:10.1093/aob/mcs209

Oberson A, Frossard E, Buhlmann C, Mayer J, Mader P, Luscher A (2013) Nitrogen fixation and transfer in grass-clover leys under organic and conventional cropping systems. Plant Soil 371:237-255 doi:10.1007/s11104-013-1666-4

Özbek H (2011) Sainfoin, Onobrychis viciifolia Scop. : An important bee plant. Uludag Bee Journal $11: 51-62$

Parker RJ, Moss BR (1981) Nutritional-value of sainfoin hay compared with alfalfa hay. J Dairy Sci 64:206-210 doi:10.3168/jds.S0022-0302(81)82555-6

Peralta M, Combes M-C, Cenci A, Lashermes P, Dereeper A (2013) SNiPloid: a utility to exploit high-throughput SNP data derived from RNA-seq in allopolyploid species. International journal of plant genomics 2013:890123 doi:10.1155/2013/890123

Piano E, Pecetti L (2010) Minor legume species. In: Boller B, Posselt UK, Veronesi F (eds) Fodder Crops and Amenity Grasses. Handbook of Plant Breeding, vol 5. Springer Science + Business Media, New York, pp 477-500. doi:10.1007/978-1-4419-0760-8

Piper C (1914) Forage plants and their culture. The Rural Text-Book Series. The Macmillan company, New York, USA

Porcher MH (2004) Sorting Onobrychis Names. Multilingual Multiscript Plant Name Database - A Work in Progress. The University of Melbourne. 
Posselt U (2010) Breeding methods in cross-pollinated species. In: Boller B, Posselt U, Veronesi F (eds) Fodder Crops and Amenity Grasses. Handbook of Plant Breeding, vol 5. Springer Science + Business Media, New York, pp 39-88. doi:10.1007/978-1-4419-0760-8

Quijada J, Fryganas C, Ropiak HM, Ramsay A, Mueller-Harvey I, Hoste H (2015) Anthelmintic Activities against Haemonchus contortus or Trichostrongylus colubriformis from Small Ruminants Are Influenced by Structural Features of Condensed Tannins. J Agric Food Chem 63:6346-6354

Regos I, Urbanella A, Treutter D (2009) Identification and Quantification of Phenolic Compounds from the Forage Legume Sainfoin (Onobrychis viciifolia). J Agric Food Chem 57:58435852 doi:10.1021/Jf900625r

Rumball W, Claydon RB (2005) Germplasm release - 'G35' Sainfoin (Onobrychis viciifolia Scop.).

Sacristan M (1966) Estudios citotaxonomicos sobre el genero Onobrychis (L) Adanson con referencia especial a la citogenetica de la esparceta (Onobrychis viciifolia Scop.). Anales de la Estacion Experimental de Aula Dei 8:1-115

Sanderson MA, Brink G, Ruth L, Stout R (2012) Grass-legume mixtures suppress weeds during

Sears RG, Ditterline RL, Mathre DE (1975) Crown and root rotting organisms affecting sainfoin (Onobrychis viciifolia) in Montana. Plant Dis Rep 59:423-426

Sergeeva AG (1955) The effect of lucerne and sainfoin on the water-stable structure of soils under

Sheehy JE, Popple SC (1981) Photoynthesis, water relations, temperature and canopy structure as factors influencing the growth of sainfoin (Onobrychis viciifolia Scop.) and lucerne (Medicago sativa L.). Ann Bot 48:113-128 
Sölter U, Hopkins A, Sitzia M, Goby JP, Greef JM (2007) Seasonal changes in herbage mass and nutritive value of a range of grazed legume swards under Mediterranean and cool temperate conditions. Grass Forage Sci 62:372-388 doi:10.1111/j.1365-2494.2007.00592.x

Sottie E, Acharya S, McAllister T, Thomas J, Wang Y, Iwaasa A (2014) Alfalfa pasture bloat can be eliminated by intermixing with newly-developed sainfoin population. Agron J 106:14701478

Sottie ET (2014) Characterization of new sainfoin populations for mixed alfalfa pastures in western canada. PhD Thesis, University of Lethbridge

Stamp N (2003) Out of the quagmire of plant defense hypotheses. Q Rev Biol 78:23-55 doi:10.1086/367580

Stringano E, Carbonero CH, Smith LMJ, Brown RH, Mueller-Harvey I (2012) Proanthocyanidin diversity in the EU 'HealthyHay' sainfoin (Onobrychis viciifolia) germplasm collection. Phytochemistry 77:197-208 doi:10.1016/j.phytochem.2012.01.013

Suter M, Connolly J, Finn JA, Loges R, Kirwan L, Sebastia MT, Lüscher A (2015) Nitrogen yield advantage from grass-legume mixtures is robust over a wide range of legume proportions and environmental conditions. Global Change Biology 21:2424-2438 doi:10.1111/gcb.12880

Tasei JN (1984) Légumineuse fourragères et protéagireusses. In: Pessan P, Louveaux J (eds) Pollinisation et productions végétales. INRA, Paris, France, pp 285-287

Taylor NL, Anderson MK (1980) Maintenance of Parental Lines for Hybrid Red-Clover. Crop Sci 20:367-369

Thomson JR (1938) Cross- and self-fertility in sainfoin. Ann Appl Biol 25:695-704 doi:10.1111/j.1744-7348.1938.tb02348.x

Treutter D (2006) Significance of flavonoids in plant resistance: a review. Environ Chem Let 4:147 doi:10.1007/s10311-006-0068-8

Trnka M, Olesen JE, Kersebaum KC, Skjelvåg AO, Eitzinger J, Seguin B et al. (2011) Agroclimatic conditions in Europe under climate change. Global Change Biology 17:2298-2318 doi:10.1111/j.1365-2486.2011.02396.x 
Turk M, Albayrak S, Tuzun C, Yuksel O (2011) Effects of fertilization and harvesting stages on forage yield and quality of sainfoin (Onobrychis sativa L.). Bulgarian J of Agric Sci 17:789794

Varshney RK, Graner A, Sorrells ME (2005) Genomics-assisted breeding for crop improvement. Trends Plant Sci 10:621-630 doi:10.1016/j.tplants.2005.10.004

Veronesi F, Brummer EC, Huyghe C (2010) Alfalfa. In: Boller B, Posselt UK, Veronesi F (eds) Fodder Crops and Amenity Grasses. Handbook of Plant Breeding, vol 5. Springer Science + Business Media, New York, pp 395-438. doi:10.1007/978-1-4419-0760-8

Waghorn G (2008) Beneficial and detrimental effects of dietary condensed tannins for sustainable sheep and goat production-Progress and challenges. Anim Feed Sci Technol 147:116-139 doi:10.1016/j.anifeedsci.2007.09.013

Wang Y, Berg BP, Barbieri LR, Veira DM, McAllister TA (2006) Comparison of alfalfa and mixed alfalfa-sainfoin pastures for grazing cattle: Effects on incidence of bloat, ruminal fermentation, and feed intake. Can J Anim Sci 86:383-392 doi:doi.org/10.4141/A06-009

Wang Y, Majak W, McAllister TA (2012) Frothy bloat in ruminants: Cause, occurrence, and mitigation strategies. Anim Feed Sci Technol 172:103-114 doi:10.1016/j.anifeedsci.2011.12.012

Wang Z, Gerstein M, Snyder M (2009) RNA-Seq: a revolutionary tool for transcriptomics. Nat Rev Genet 10:57-63 doi:10.1038/nrg2484

Wilman D, Asiedu FHK (1983) Growth, nutritive-value and selection by sheep of sainfoin, redclover, lucerne and hybrid ryegrass. J Agric Sci 100:115-126

Woodgate K, Maxted N, Bennett SJ (1999) A generic conspectus of the forage legumes of the Mediterranean basin. In: Bennett SJ, Cocks PS (eds) Genetic Resources of Mediterranean pasture and forage legumes. Springer Science + Business Media, Dordrecht, Germany, p 204

Zarrabian M, Majidi MM, Ehtemam MH (2013) Genetic diversity in a worldwide collection of sainfoin using morphological, anatomical, and molecular markers. Crop Sci 53:2483-2496 doi:10.2135/cropsci2013.03.0130 
824 Zuppinger-Dingley D, Schmid B, Petermann JS, Yadav V, De Deyn GB, Flynn DF (2014)

825 Selection for niche differentiation in plant communities increases biodiversity effects.

$826 \quad$ Nature 515:108-111 doi:10.1038/nature13869

827 
1 Table 1: Variation for key breeding targets in sainfoin (Onobrychis viciifolia Scop.) germplasm $\left(\mathrm{DMY}=\mathrm{dry}\right.$ matter yield $\left[\mathrm{t}\right.$ ha $\left.{ }^{-1}\right]$, $\mathrm{PH}=\mathrm{plant}_{\mathrm{f}}$ height $2[\mathrm{~mm}], \mathrm{SY}=$ seed yield $\left[\mathrm{kg} \mathrm{ha}^{-1}\right], \mathrm{TF}=$ time to flowering [days], $\mathrm{CP}=$ crude protein $\left[\mathrm{g} \mathrm{kg}^{-1} \mathrm{DM}\right], \mathrm{NDF}=$ neutral detergent fiber $\left[\mathrm{g} \mathrm{kg}^{-1} \mathrm{DM}\right], \mathrm{ADF}=$ 3 acid detergent fiber $\left[\mathrm{g} \mathrm{kg}^{-1} \mathrm{DM}\right], \mathrm{PA}=$ proanthocyanidin $\left[\mathrm{g} \mathrm{kg}^{-1} \mathrm{DM}\right], \mathrm{PDS}=$ prodelphinidin share of CT [\%])

\begin{tabular}{|c|c|c|c|c|c|c|c|c|c|c|}
\hline \multicolumn{4}{|c|}{ Agronomic traits } & \multicolumn{5}{|c|}{ Quality traits } & \multirow[t]{2}{*}{ Remarks } & \multirow[t]{2}{*}{ Reference } \\
\hline DMY & $\mathrm{PH}$ & SY & $\mathrm{TF}$ & $\mathrm{CP}$ & NDF & $\mathrm{ADF}$ & $\mathrm{CT}$ & PDS & & \\
\hline $6.4-8.1$ & $603-742$ & $207-551$ & $50-52$ & & & & & & 10 accessions & Mohajer et al. (2011) \\
\hline $11-13$ & & & & & & & $17-24^{1}$ & & 3 accessions & Häring et al. (2008) \\
\hline $5.9-8.4$ & & & & $227-240$ & $351-398$ & $305-352$ & & & Rainfed, pure stands & Acharya (2015) \\
\hline \multirow[t]{2}{*}{$9.8-12.0$} & & & & $156-182$ & $378-417$ & $349-372$ & $46.9-68.7^{1}$ & & 15 accessions & Azuhnwi et al. (2011) \\
\hline & & & & & & & $3.2-17.8^{2}$ & $48-74$ & 6 accessions & Azuhnwi et al. (2013a) \\
\hline $0.5-8.0$ & & & & $224-234$ & $211-246$ & & & & CP, NDF: leaves & Borreani et al. (2003) \\
\hline $2.3-11.3$ & & & & $148-232$ & $264-488$ & & & & Pure stands & Liu et al. (2008) \\
\hline $3.9-7.6$ & & & & $157-198$ & $374-489$ & $283-370$ & & & Seasonal development & Turk et al. (2011) \\
\hline $9.3-378.3^{3}$ & $140-900$ & & $13-67$ & & & & & & 26 accessions & Zarrabian et al. (2013) \\
\hline $10.4-58.1^{3}$ & $376-459$ & & & & & & & & 10 accessions & Irani et al. (2015) \\
\hline \multirow[t]{7}{*}{$0.3-20.3^{3}$} & & & & & & & $23.0-47.5^{4}$ & $79-96$ & 27 accessions; $\mathrm{CT}$ in leaves & Malisch et al. (2015) \\
\hline & $80-1290$ & $0-4608^{5}$ & $19-65$ & & & & $9.7-47.2^{4}$ & $76-93$ & Segregating populations & Kempf et al. (2017) \\
\hline & & & & $116-143$ & $372-457$ & $368-392$ & & & & Parker and Moss (1981) \\
\hline & & & & 121 & 478 & 433 & & & & Khalilvandi-Behroozyar et al. (2010) \\
\hline & & & & $131-195$ & $461-557$ & $334-406$ & $42.6-105.2^{1}$ & & Seasonal development & Bal et al. (2006) \\
\hline & & & & $114-177$ & $431-476$ & $343-433$ & $41.9-99.5^{1}$ & & 5 accessions & Kaplan (2011) \\
\hline & & & & $125-161$ & & $313-371$ & $11.0-46.0^{1}$ & & & McMahon et al. (1999) \\
\hline
\end{tabular}

\footnotetext{
$4 \quad{ }^{1} \mathrm{HCl}$ - buthanol method

52 thiolysis method

$6 \quad 3$ single plants; g plant ${ }^{-1}$

$7 \quad{ }^{4}$ UPLC MS/MS method

$8 \quad{ }^{5}$ seed number plant ${ }^{-1}$
} 